Where there can hardly be said to be any malaria; he came into Africa at the very safest season of the year, had been excellently looked after, and had hardly suffered at all from ferer; indeed, the gentleman in whose service he was, and who has seen a good deal of African fever, told me that the very slight attacks of fever which the man had previous to my examining him were so mild that he doubted whether they were attacks of fever or of temper. Although we must never forget the very insidious nature of the malarial poison, and how it may thoroughly undermine the system without giving any gross sign of its action, yet we must bear in mind that this slow poisoning only occurs under special conditions, amongst which is a somewhat prolonged stay in a markedly malarial district. In persons whose systems have been thus undermined by the poison rupture of the spleen may be readily caused by any trivial accident, such as a slight blow over the spleen or even by a much less strain, as in a case I heard of where a gentleman ruptured his spleen by vigorously stretching himself after his bath. In all these cases, however, the splenic tissue has been greatly altered-the capsule has lost its toughness and elasticity. Dr. Barrallier gives two cases of rupture of the spleen during first attacks of ague. I have not been able to get his original article, but in one of your contemporaries, ${ }^{1}$ where it is quoted, mention is made of both spleens being found softened on post-mortem examination. So I presume the patient had been exposed for some time to the poison or had suffered some days from the fever. Although in most books it is said that the rush of blood to the spleen in cases of malarial fever may be so great as to cause rupture of that organ, yet when we consider the many thousands of cases of ague which occur every day and the exceedingly rare occurrence of rupture I think we may fairly conclude that something more than a mere increased blood pressure is required to trust the very tough and resistant capsule. In most cases this extra factor is found in the degenerated condition of the splenic tissues-a cause, however, which in this case neither the history nor the post-mortem appearances warrant us in accepting. I think an extra factor or predisposing cause might perhaps be found in the utterly depraved condition of the patient's nervous system, as revidenced by the intense anxiety and dread which he showed. Gueryone knows the evil influence which great mental worry and an emotional condition exert on the bodily functions, and from time immemorial the spleen has been debited with being specially affected by conditions of anxiety and depression. How far this old belief is correct has yet to be ascertained; but the investigations of Botkin of St. Petersburg, who found that depressing emotions cansed an increase in the size of the spleen, give some little

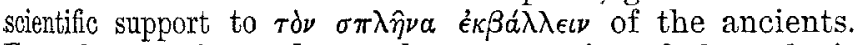
From the extensive and very clear separation of the splenic capsule from the parenchyma it would almost seem as if the hæmorrhage had been first subcapsular (though no varicose or distended veins were found in the substance of spleen post mortem), and that the blood had made room for itself by tearing through the splenic trabeculæ and pressing the parenchyma backwards, the blood gradually increasing and finally rupturing the capsule. As I have noted, the patient experienced a distinct relief from the pain about $8 \mathrm{~A}$. M. ; the relief was very decided, and he showed it by his movements. It is very improbable that the morphia-which for want of a reliable subcutaneous solution was given in the form of pills - and the champagne could have any effect, as the stomach could hardly have absorbed them. It is just possible the relief experienced was due to the rupture of the capsule relieving the tension of the pentup blood. This might also explain the fact that when I first saw the patient, ten hours after the rupture, which I date from the first complaint of pain at the heart, the mucous membranes and tongue were more livid than pale. The amount of liquid which the stomach contained was much greater than the amount the patient had received for at least six hours, and as the intestines were absolutely empty it would seem that the stomach had neither been able to absorb the liquid nor to pass it on to the duodenum for several hours before death. The albuminuria in the little urine drawn off doubtless arose from the damaging of the epithelium of the capillary tufts, which is said to occur whenever a full stream of arterial blood is not kept flowing through them. The symptoms presented an interesting

1 Brit. Med. Jour., vol. j. 1891, p. 376. mixture of those of collapse and of homorrhage, several of the prominent symptoms of both being wanting and many modified or obscured.

Blantyre, East Central Africa.

\section{FRACTURE (DISLOCATION) OF SPINE; REDUCTION; TEMPORARY RECOVERY.}

BY W. ARBUTHNOT LANE, M.S., F.R.C.S. ENG., ASSISTANT SURGEON TO GUY'S HOSPITAL AND TO THE HOSPITAL FOR SICK CHILDREN.

W. J-a a a ed eighteen, was struck in the back by a heary iron gate, which fell upon him. He was admitted into Guy's Hospital at $1.30 \mathrm{P.M}$. on June 13th, where he was found to have some deformity of the spine about the tenth and eleventh dorsal vertebræ, between the spinous processes of which a gap of some extent could be felt. He then had apparently cornplete or nearly complete power over his legs as he lay on his back in bed. By about four o'clock he began to complain of pain in his legs and in the lower part of the abdomen, and when asked to move his legs he did so with much difficulty and but to a slight extent. It was impossible to say how far his inability to perform any movement was due to a loss of control over the muscles or to a disinclination to make any alteration in the position of the limbs owing to a consequent increase in the pain from which he suffered. Probably both conditions existed. As time went on the hyperæsthesia became more marked. and any movement or noise in the vicinity of the bed exaggerated his pain greatly. This was most obvious below the knees. Sensation was at the same time much modified. For instance, pulling a hair of his leg caused him great pain, though he could not tell what had been done. The reflexes were much exaggerated.

Mir. Golding-Bird saw the patient just after his admission, before any of the above symptoms had developed, and in his absence I saw him at 11.30 P.M. As the symptoms were steadily increasing in severity $I$ determined to operate at once. A long incision being made and the spinal muscles having been turned aside, it was found that the tenth dorsal vertebra was displaced forwards and slightly downwards, so that the cord was compressed between the laminæ of the tenth and the body of the eleventh dorsal vertebræ. The displacement was not considerable, so that the cord was apparently squeezed rather than crushed. The interspinous ligament was torn through. As the lower articular processes of the tenth dorsal vertebra lay in front of the upper articular processes of the eleventh dorsal vertebra the latter were cut away. After great difficulty the tenth dorsal vertebra was dragged back into its normal position. This was effected partly by over-extending the dorsal spine and partly by traction exerted upon the spinous process by lion forceps. As on the removal of this traction the displacement recurred, I passed a stout silk ligature between the spinous processes of the ninth and tenth and the eleventh and twelfth dorsal vertebra, and by that means tied the tenth and eleventh spinous processes immovably together.

On Jume 14th the symptoms continued as before the operation. On the 15th they diminished slightly but distinctly. On the 16th the improvement continued, but it was still necessary to give morphia to control the hyperæsthesia. By the 21st the hyperæesthesia had disappeared, and he could move his legs a little, apparently without pain. 'The silk ligatune was then removed. By the 26 th he appeared to have recovered complete control over his legs. The spinous processes were in good position over the same transverse plane. The reflexes were then normal. The patient was extremely troublesome and restless throughout, and after the wound had apparently healed firmly it broke down, a portion of a spinous process coming away, when the ligature, being useless, was removed. He kept constantly rolling about, and complete paraplegia soon developed. The spine was then explored, when the vertebræ were found to be displaced laterally upon one another and the cord was completely divided. This unfortunate result was due solely to the extremely troublesome character of the patient, a poor halfstarved, half-witted creature, whom it was found impossible to control satisfactorily by any means.

The case is one of much interest, and resembles more or 
ess closely one published by Mr. Golding-Bird last year. It would appear that the symptoms in this case were due to pressure rather than to the presence of hæmorrhnge inside the cord. It was evident at the time of the operation that there was no such considerable collection of blood inside the sheath of the dura mater as could produce symptoms of compression, and one was surprised that there was not more paralysis, since the cord appeared to be compressed within narrow limits by the displaced vertebræ.

St. Thomas's-street, S.E.

\section{Clinital a}

\section{MEDICAL, SURGICAL, OBSTETRICAL AND THERAPEUTICAL.}

\section{CONVULSION TREATED BY COMPRESSION OF THE CARO'TID. \\ By T. Gordon Kelly, M.D. Dub.}

IN the issue of THE LANCET of Jan. 2nd I read an account of Dr. Leopold Roheim's treatment of eclampsia by compression of the carotid, and in a subsequent number an account of a case of convulsion where this treatment was successfully tried by Mr. W. C. Hearnden. A similar case occurred in my practice a short time ago, the following notes of which may be of interest.

Mrs. H_ a married woman aged sixty-four, had been under my care for over two years, suffering from chronic rheumatism, renal troubles \&c. I had not seen her for some months previously. I rode off immediately, and on my arrival found the patient in a fit which I was told had lasted one hour and a half. The pulse was full, respiration noisy and laboured, and the muscles of her face and body were convulser. I determined to try Dr. Roheim's treatment. Except for the force with which the carotid was beating, I found this comparatively easy to do, the woman being very thin. Within a few moments from placing my thumb on the artery the convulsions of the face and body began to cease, the respiration gradually became slower and deeper, and in about two minutes and a half she came out of the fit, looked around in a dazed way, and when I asked her if she was better, nodded her head in reply. Since then she has had no return of the attack.

Desford, Leicester.

\section{A CASE OF TETANCS WITH DOUBLE FACIAL PARALYSIS ; RECOVERY.}

BY W. Huntington, M.R.C.S. Evg., L.R.C.P. Lond.

J. K- , aged fourteen, farm servant, fell and cut his head on Jan. 4th. The mother covered the wound with stamp plaster, which was allowed to remain adhering for a week. Pus was then observed coming from under the paper, so a poultice was applied and the dressing removed. A day or two after this he complained of stiffiness in the jaws and neck, and this increased until the fifteenth day after the injury, when his jaws became firmly locked and he could scarcely swallow. I saw him for the first time on the sixteenth day after the injury. The wound, which had evidently been a badly contused one, was nearly healed, and rather more than an inch in length. It was situated on the forehead, running obliquely upwards and to the left from a little above the root of the nose. He was sitting in a chair and would not lie in a bed, since he found the latter position more irksome and caused worse exacerbations. He could not endure darkness or noise, and required a light all night. His jaws were close together and rigid; masseter, temporal and sterno-mastoid muscles firmly contracted; intellect clear ; face expressionless ; when asked to smile, he said he could not ; nor could he properly close his eyes. There was complete paralysis of muscles of both sides of the face. The pupils reacted to light and accommodation and the movements of the eyes were normal. He suffered from frequent cramps in the legs and abdomen. His arms moved awkwardly, and the grip of the hands was feeble. Dysphagia was a prominent symptom.
There was a profuse flow of saliva, which ran out of his mouth; he suffered much from sleeplessness, for many days and nights only obtaining a few minutes' sleep at a time He was given a mixture of chloral hydrate with bromide of potassium and tincture of hyoscyamus every three hours, and at night he had opium in addition. In a week's time the paralysis on the left side of the face began to subside, and in another week the right side did likewise, and he was then soon able to whistle, smile \&c. At first he could not walk, but after a fortnight he could do so with assistance ; and his action was peculiar, each leg being moved forward from the hip as if rigid tbrough its length, the foot dragging along the ground. The symptoms gradually subsided, and in six weeks he was practically well and able to go away for a change. A short time ago (June) I saw him, and he was in perfect health.

This case reminds one of the form described by Rose of Zürich, and called by him "cephalic tetanus"; but, so far as I am aware, only one side of the face was paralysed in the cases mentioned. From the dysphagia and irritation caused by noise and movement the term "hydrophobic tetanus," already used to some cases of this disease, would here be an apt one st. Andrews, N.B.

\section{THE IMPORTANCE OF OBSTRUCTION TO THE OUTFLOW OF CRINE AS A CAUSE OF PUERPERAL ECLAMPSIA.}

By G. E. Hale, M.B., B.C. Cantab.

THE following brief note concerning a necropsy which $l$ performed a short time ago may be of value to those who, like myself, were interested in Mr. Gifford Nash's paper, published in THE LANCET of Aug. 27th, on the above subject. The girl had died of double pleurisy with a little pneumonia, which had commenced suddenly with a rigor six days before her death. She was pregnant for the first time with a six-months' fœetus. Both ureters from the kidneys to the brim of the pelvis were dilated up to the size of the common iliac artery, while the kidneys were in a condition of slight hydronephrosis, with much congestion of their substance. No obstruction could be found within the canal of the ureters to account for this distension, and the whole condition strongly suggested that the ureters had been obstructed from without by the pressure of the pregnant uterus. The urine during her stay of four days in the hospital was highly albuminous and containet also a trace of deutero-albumose.

St. George's Hospital.

\section{d a tlitror \\ OF}

\section{HOSPITAL PRACTICE, BRITISH AND FOREIGN.}

Nulla autem est alia pro certo noscendi via, nisi quamplurimas et mor borum et dissectionum historias, tum aliorum tum proprias collectas habere, et inter se compare.-MORGAGNI De Sed. et Caus. Morb., habere, et inter

\section{ST. BARTHOLOMEW'S HOSPITAL.}

OSTEO-SARCOMA OF THE HUMERUS WEIGHING THIRTY THREE POUNDS AND MEASURING THIRTY-ONE INCHES IN CIRCUMFERENCE; LIGATURE AT THE SUBCLAVIAN ARTERY AND AMPUTATION AT THE SHOULDER-JOINT; RECOVERY.

(Under the care of Mr. Howand MaRsH.)

THIs case is worthy of being recorded, for the tumour must be one of the largest ever removed with the upper extremity. The history of the case points to the formation of a cartilaginous tumour in the first instance, and after some years the rapid development in that of sarcomatous tissue. Pollet ${ }^{1}$ reported last year a case of large osteo-sarcoma of the femur, which was supposed to have been in existence for twenty-five years. The success of an operation for such a large growth as this depends very much on the efficient 